\title{
Comparative anatomical investigation of five Artemisia L. (Anthemideae, Asteraceae) species in view of taxonomy
}

\author{
Pedja Janaćković ${ }^{1}$ (1) $\cdot$ Milan Gavrilović ${ }^{1}$ - Dragana Rančić ${ }^{2}$ - Zora Dajić-Stevanović ${ }^{2}$ - Abdulhmid A. Giweli ${ }^{3}$. \\ Petar D. Marin ${ }^{1}$
}

Received: 29 November 2018 / Accepted: 21 February 2019 / Published online: 18 March 2019

(c) Botanical Society of Sao Paulo 2019

\begin{abstract}
Comparative anatomical analysis of vegetative organs has been conducted on Artemisia campestris L., A. absinthium L., A. arborescens L., A. judaica L. and A. herba-alba Asso, using light microscopy, in order to examine the most important anatomical features and to find new valid taxonomic characters. Results have shown that general root, stem and leaf anatomical features and nonglandular and glandular trichomes are shared by all species. However, some characters (parenchyma sheath, which surrounded vascular bundle and extended to both epidermises, subepidermal collenchyma and the absence of secretory canals in the leaves) link together A. absinthium and A. arborescens from the same section. Some characters, as periderm and lignified pith parenchyma cells (A. campestris and A. arborescens), nonendodermal secretory canals in root cortex (A. absinthium and A. judaica) and secretory canals in the leaf phloem (A. judaica and A. herba-alba), connect species belonging to different sections. Moreover, some characters could be considered as species-specific, nonendodermal secretory canals in the root secondary phloem, triangular leaf shape on the cross section and secretory canals in the leaf parenchyma for A. campestris, secretory canals in the stem pith for A. absinthium, crystals in the pith parenchyma cells for A. arborescens and the absence of root secretory canals for $A$. herba-alba. Given results revealed qualitative characters, on the basis of which the studied species are anatomically distinguishable between each other, provide valuable features for better species identification and contribute to the anatomy of the genus Artemisia.
\end{abstract}

Keywords Leaf $\cdot$ Root $\cdot$ Secretory canals $\cdot$ Stem $\cdot$ Trichomes

\section{Introduction}

One of the largest angiosperm family, Asteraceae, includes hundreds of species of economic interest, e.g., medicinal plants which are used therapeutically, and consequently, their anatomy and morphology have been studied, including the structures which produce and storage specialized metabolites (Werker and Fahn 1981; Ascensão and Pais 1987;

Pedja Janaćković

pjanackovic@bio.bg.ac.rs

1 Chair of Plant Morphology and Systematics, Institute of Botany and Botanical Garden "Jevremovac", Faculty of Biology, University of Belgrade, Studentski trg 16, 11000 Belgrade, Serbia

2 Department of Agrobotany, Faculty of Agriculture, University of Belgrade, Nemanjina 6, 11080 Belgrade, Serbia

3 Department of Botany, Faculty of Science, University of Al - Gabel Al - Gharbe, Zintan, Libya
Figueiredo and Pais 1994; Ascensão et al. 2001; Andreucci et al. 2008; Simpson 2009; Camilotti et al. 2014; Gavrilović et al. 2016). These secretory structures in Asteraceae could be found in the form of glandular trichomes, cavities, canals, laticifers, hydathodes, idioblasts and glandular appendices (Metcalfe and Chalk 1950; Carlquist 1958; Lestern and Curtis 1985; Castro et al. 1997; Gavrilović et al. 2018a). In addition, an importance of these structures in taxonomic studies was emphasized by some authors (Solereder 1908; Metcalfe and Chalk 1950, 1979; Metcalfe 1983), with the main purpose of distinguishing orders, tribes, genera and even certain species, because various secretory structures may be found in a different parts of the same plant or be only located in certain plant organs.

Likewise, all other vegetative anatomical characters are also useful in taxonomic studies and are important in perceiving phylogenetic relationships of particular plant groups (Lersten and Curtis 2001; Dengler 2002). Anatomical data also may provide useful and valuable characters which may 
help in identification of ambiguous plant taxa, as well as establishing their taxonomic relationships (Metcalfe and Chalk 1957; Scatena et al. 2005; Sosa et al. 2014; Karanović et al. 2015; Gavrilović et al. 2018b). Also, micromorphological characteristics, e.g., trichomes, have played an important role in plant taxonomy at generic and species levels (Hayat et al. 2009; Gavrilović et al. 2018b).

Genus Artemisia L. (Artemisiinae, Anthemideae, Asteraceae) contains more than 500 taxa (Vallès and Garnatje 2005) mainly distributed in temperate areas of the northern hemisphere, colonizing mainly arid and semiarid habitats, with a few representatives in the southern hemisphere (McArthur and Plummer 1978; Pellicer et al. 2010). Apart from few annuals or biennials, most of the Artemisia species are perennial (Vallès et al. 2003). As Artemisia species have wide range of geographical distribution and also a variety of habitats on which they occur, it may result in different adaptations to diverse conditions (Kreitschitz and Vallès 2007), e.g., changes in morphology and anatomy, as well in the cell structure and function (increase in ploidy level and nuclear DNA content) (Garcia et al. 2004). Notably, many Artemisia species are used as food, medicinal and ornamental plants (Pareto 1985), whereas others are toxic or allergenic and invasive plants (Tan et al. 1998).

Although worldwide research on Artemisia taxa is ongoing, it is mainly focused on phytochemistry, as well as investigations of biological activities of different extracts or essential oils, or pure compounds. Still, little is known about anatomical aspects and its value in taxonomy of the genus Artemisia. Metcalfe and Chalk (1957) mentioned some anatomical features of Artemisia: nonglandular trichomes, medullary canals, secretory cavities and clustered crystals. However, there are several studies on anatomy (Carlquist 1966; Botha and Evert 1981; Fahmy 1997; Marchese et al. 2005; Rabie et al. 2006; Noorbakhsh et al. 2008; Bercu and Broască 2012; Konowalik and Kreitschitz 2012; Bakr 2014; Maghni et al. 2018) and trichome morphology (Kelsey 1984; Ascensão and Pais 1987; Lodari et al. 1989; Ferreira and Janick 1995; Hayat et al. 2009, 2010) of the genus Artemisia.
Infrageneric taxonomy of the genus Artemisia is ambiguous and still represents a challenging task for taxonomists. Based mainly on the capitula type and florets fertility, five major groups are recognized in the traditional studies: Absinthium DC., Artemisia, Dracunculus Besser, Seriphidium Besser and Tridentate (Rydb.) McArthur (Torrell et al. 1999). However, latest phylogenetic studies on Artemisia s.str., using nrDNA ITS sequences, support the monophyly of the genus and the monophyly of the three main infrageneric groups (Dracunculus, Seriphidium, Tridentate), whereas subgenera Absinthium and Artemisia are polyphyletic (Watson et al. 2002; Vallès et al. 2003; Sanz et al. 2008).

The objectives of the present study were: (1) to conduct comparative anatomical analysis of root, stem and leaves of A. campestris L., A. absinthium L., A. arborescens L., A. judaica L. and A. herba-alba Asso in order to evaluate their taxonomic value; (2) to examine the important anatomical features and try to find new valid taxonomic characters, which will contribute to anatomy of the genus and provide characters for better identification of the species.

\section{Materials and methods}

Plant material - We have chosen five species belonging to different sections, as well as from different origins: $A$. campestris, A. absinthium, A. arborescens, A. judaica and A. herba-alba (Table 1). Plant material (parts of root, stem and middle leaves on the stem) (five individuals per species, except for $A$. arborescens, which was only one-old individual) was collected in Serbia, Montenegro and Libya during the flowering period (2012 and 2016) and kept in $50 \%$ ethanol. Voucher specimens were deposited in the Herbarium (BEOU) of University of Belgrade-Faculty of Biology, Institute of Botany and Botanical Garden "Jevremovac" (Table 1).

Anatomical analysis - Temporary and permanent slides of mature roots, stems and leaves of adult plants were

Table 1 List of the examined Artemisia species

\begin{tabular}{|c|c|c|c|c|c|}
\hline Species & Section & Locality & Coordinates & Date & Voucher numbers (BEOU) \\
\hline A. campestris $\mathrm{L}$. & Dracunculus & Podgorica (Montenegro) & $\begin{array}{l}\text { N } 42^{\circ} 24^{\prime} 43^{\prime \prime} \\
\text { E } 19^{\circ} 15^{\prime} 1^{\prime \prime}\end{array}$ & 2016 & 17434 \\
\hline A. absinthium $\mathrm{L}$. & Absinthium & Đerdap (Serbia) & $\begin{array}{l}\text { N } 44^{\circ} 64^{\prime} 996^{\prime \prime} \\
\text { E } 22^{\circ} 54^{\prime} 674^{\prime \prime}\end{array}$ & 2016 & 17438 \\
\hline A. arborescens L. & Absinthium & Budva (Montenegro) & $\begin{array}{l}\text { N } 42^{\circ} 16^{\prime} 37.49^{\prime \prime} \\
\text { E } 18^{\circ} 50^{\prime} 19.66^{\prime \prime}\end{array}$ & 2016 & 17432 \\
\hline A. judaica $\mathrm{L}$. & Artemisia & Zintan (Libya) & $\begin{array}{l}\mathrm{N} 29^{\circ} 33^{\prime} 44.97^{\prime \prime} \\
\mathrm{E} 10^{\circ} 14^{\prime} 15.13^{\prime \prime}\end{array}$ & 2012 & AJU04022012 \\
\hline A. herba-alba Asso & Seriphidium & Zintan (Libya) & $\begin{array}{l}\mathrm{N} 31^{\circ} 57^{\prime} 21.19^{\prime \prime} \\
\mathrm{E} 12^{\circ} 13^{\prime} 6.35^{\prime \prime}\end{array}$ & 2012 & AHA28022012 \\
\hline
\end{tabular}


prepared. Plant parts were sectioned fresh or fixed (50\% ethanol) before preparation for a standard paraffin method (Ruzin 1999). Handmade cross sections of fresh plant material were performed using sharp razor blades. Some temporary slides (stem and leaf) were stained with toluidine blue (0.05\% w/v, aqueous) (O'Brien et al. 1964) or with Lugol solution (Johansen 1940). Paraffin method was applied for preparing cross sections $(8-10 \mu \mathrm{m}$ thick) of middle parts of mature roots, stems and leaves. Sections were double stained in Safranin O (1\%, w/v, 50\% ethanol) and alcian blue (1\% w/v, aqueous) and then were mounted on slides using Canada balsam. The permanent slides are preserved in the Chair of Morphology and Systematics of Plants, University of Belgrade - Faculty of Biology. Observations of the obtained microslides were performed on a light microscope Leica DM2000 with a digital camera Leica DFC320 and a computer with the imaging software Leica IM 1000. Classification of root secretory canals follows Tetley (1925). Investigated species are arranged phylogenetically in all tables and figures.

\section{Results}

Root - All investigated species are perennial; thus, secondary tissues are noticed in the root cross sections [especially a well-developed xylem (Figs. 1, 3, 5, 7, 9)]. A multilayered exodermis is on the surface of the root of all species (Figs. 2, 4, 6, 8, 10). Below the exodermis, a cortex is present (Figs. 2, 4, 6, 8, 10). Below cortex, secondary phloem and some groups of sclerenchyma fibers could be noticed, especially well developed in A. campestris, A. judaica and A. herba-alba (Figs. 1, 7, 10, respectively). The secondary xylem is the dominant part of the root cross sections, composed of vessels and tracheids (Figs. 3, 5, 7, 9). Endodermal secretory canals are present in the roots of A. campestris, $A$. absinthium, A. arborescens and A. judaica (Figs. 1, 3, 6, 8, respectively). Nonendodermal secretory canals are present in the secondary phloem of the root of A. campestris (Fig. 1) and in the cortex of A. absinthium (Fig. 4) and A. judaica (Fig. 8). Secretory canals in the cortex of $A$. absinthium are with some brownish content (Figs. 3, 4). Roots of A. herbaalba lack of secretory canals (Figs. 9, 10).

Stem - Young stem cross sections of all studied species have irregular pentagonal shape (Figs. 11, 13, 15, 17, 19), while later become more or less round or polygonal (Figs. 12, 14, 16, 18, 20). One-layered epidermis, composed of oval to isodiametric cells, is present on the surface of all investigated species (Figs. 12, 14, 16, 18, 20). The cortex is composed of collenchyma and chlorenchyma, which are arranged alternately. Prominent ribs in young stems contained collenchyma tissue, whereas chlorenchyma is present between the ribs (Figs. 11, 13, 15, 17, 19). Below the epidermis, well-developed periderm could be noticed only in the stem of A. campestris and A. arborescens (Figs. 12, 16). The periderm is continuous in older stems and consisted of a several layers of enlarged cells arranged in radial rows (Figs. 12, 16). The vascular bundles are collateral and arranged in a circle (Figs. 11, 13, 15, 18, 20) and separated from one another by a parenchyma tissue (Figs. 11, 13, 15, 17, 19). The primary xylem consists of four to eight parallel rows of xylem elements; each row comprised $2-5$ vessels. The vascular cylinder in a secondary state of growth produces secondary xylem inside and secondary phloem outside, giving to more basal parts of the stem almost cylindrical outline, while medullary rays on xylem side form connective tissue of lignified cells (Figs. 12, 14, 16, 18). Well-lignified sclerenchyma is above the phloem. Sclerification of the central cylinder could be noticed, because well-developed xylem and sclerenchyma tissue form a thick ring (Figs. 11, 13, 15, $18,19)$. A large parenchyma cells are in the central region of the stem of all investigated species (Figs. 11, 13, 15, 17, 19) and with lignified cell walls in A. campestris and A. arborescens (Figs. 11, 15, respectively). Crystals, in the rhomboidal form, could be noticed only inside the pith parenchyma cells of $A$. arborescens (Fig. 16, upper left). Very large secretory canals are present in the cortex of A. arborescens (Fig. 16), while small secretory canals could be seen in the cortex of A. campestris, A. absinthium, A. judaica and A. herba-alba (Figs. 12, 14, 18, 20, respectively). Small secretory canals in the pith are found only in A. absinthium stem (Fig. 14).

Leaf - Middle leaves of A. absinthium and A. arborescens possess petioles, while leaves of other investigated species are sessile. Petiole of $A$. absinthium has ellipsoidal shape, with similar anatomy as the stem (Fig. 24). On the surface is one-layered epidermis, below alternately arranged collenchyma and chlorenchyma and vascular bundles, in the center, in a circle (Fig. 24). Petiole of A. arborescens has trapezoidal shape, unstratified epidermis, alternately arranged by collenchyma and chlorenchyma, one central and two lateral vascular bundles (Fig. 27).

Leaf on the cross section is triangular in A. campestris (Figs. 21, 22), while in other studied species, A. absinthium (Fig. 25), A. arborescens (Figs. 28, 29), A. judaica (Fig. 30) and A. herba-alba (Fig. 33), is oblong-linear. On the leaf surface a cuticle could be noticed, which is very well developed in A. campestris (Figs. 21, 22). On both leaf side, one-layered epidermis could be noticed (Figs. 21, 22, 26, 28, 31, 34). The leaf blade of all investigated species is amphistomatous, and large stomatal chamber could be noticed (Figs. 21, 25, 28, 31, 33). The palisade tissue, on both leaf side, is consisted of large rich in chloroplasts cells, arranged in one or two layers. 
Figs. 1-10 Cross sections of the roots of A. campestris (1, 2), A. absinthium (3, 4), A. arborescens $(5,6)$, A. judaica $(7,8)$ and $A$. herba-alba $(9$, 10). 1, 3, 5, 7, 9 General root anatomy showing secondary structures and secretory canals. 2, 4, 6, 8, 10 Detail of the root anatomy showing endodermal $(2,6,8)$ (arrows) and nonendodermal secretory canals $(4,8)$ (arrowheads). Bar $=100 \mu \mathrm{m}$ in 2, 4 and $6 ; 200 \mu \mathrm{m}$ in $1,3,5,7$, 8,9 and 10
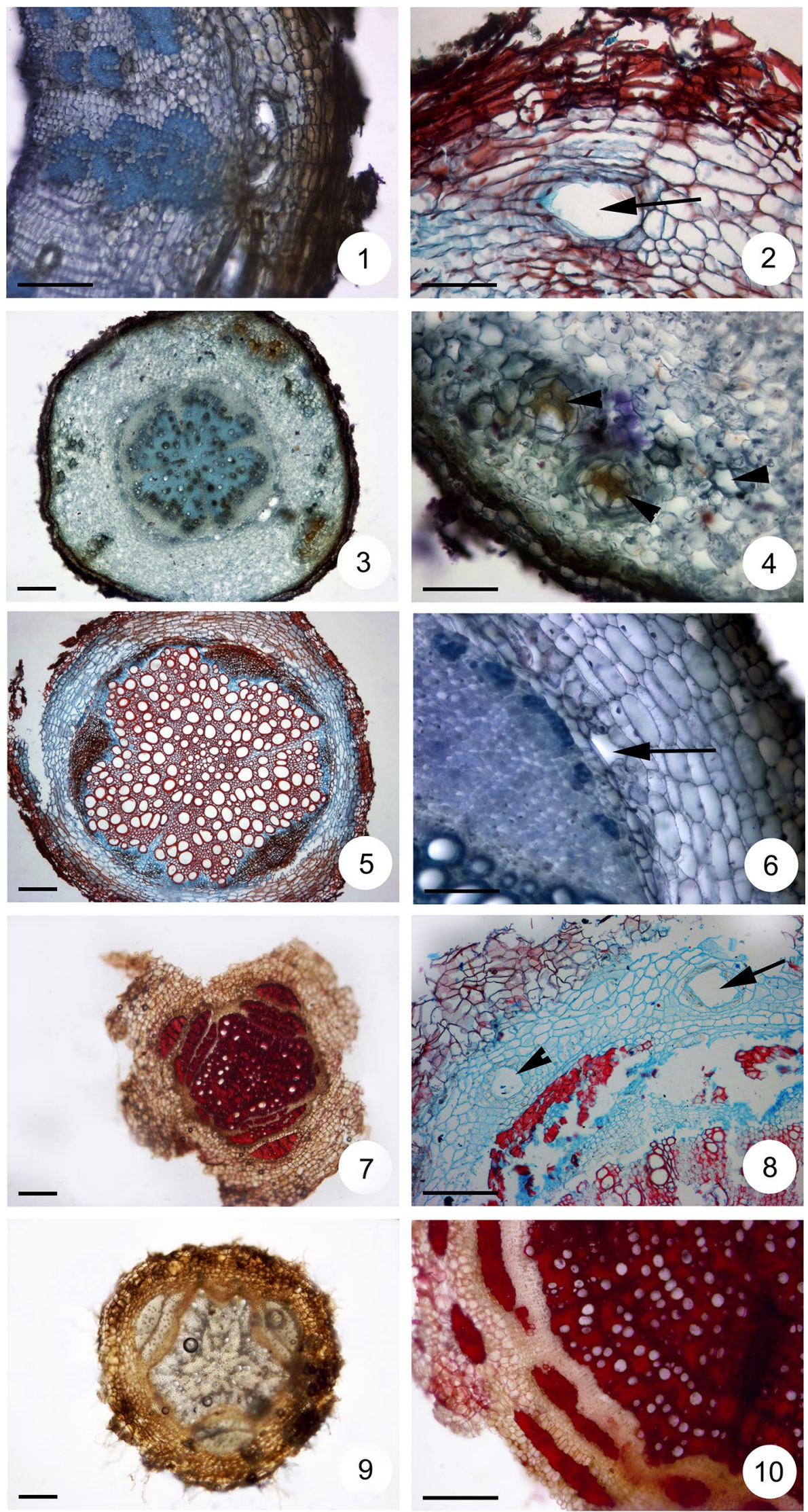
Figs. 11-20 Cross sections of the stems of A. campestris (11, 12), A. absinthium (13, 14), A. arborescens $(15,16)$, A. judaica $(17,18)$ and $A$. herba-alba $(19$, 20). 11, 13, 15, 17, 19 General stem anatomy showing secondary structures. $12,14,16,18$ 20 Detail of the stem anatomy showing periderm $(12,16)$ (arrows) and secretory canals in the cortex $(12,14,16,18,20)$ (arrowheads) and in the pith (14) (arrowhead). Bar $=50 \mu \mathrm{m}$ in $16 \mathrm{a}$ and $20 ; 100 \mu \mathrm{m}$ in 12 and $14 ; 200 \mu \mathrm{m}$ in $11,13,15,16$, 17,18 and 19
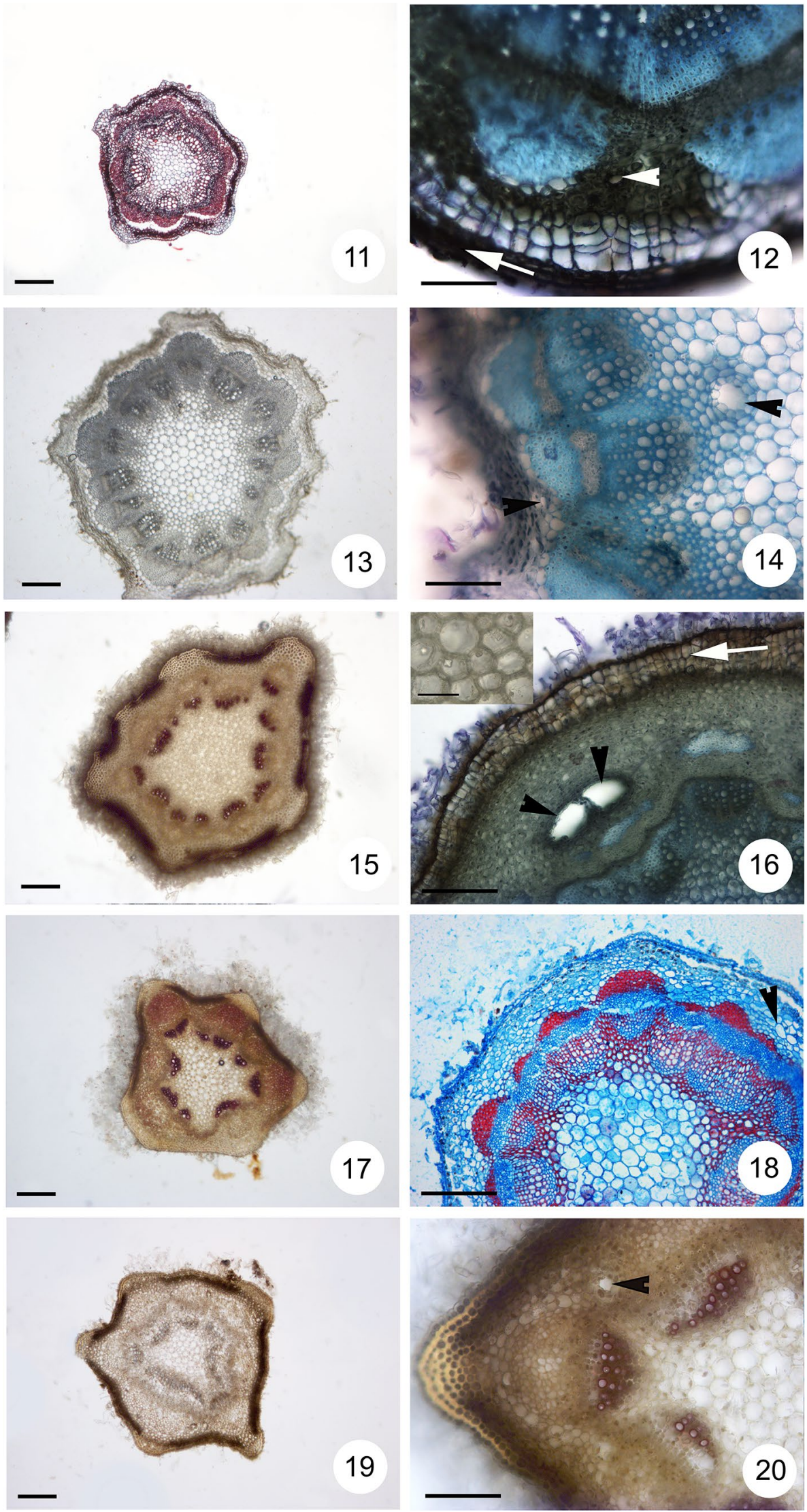


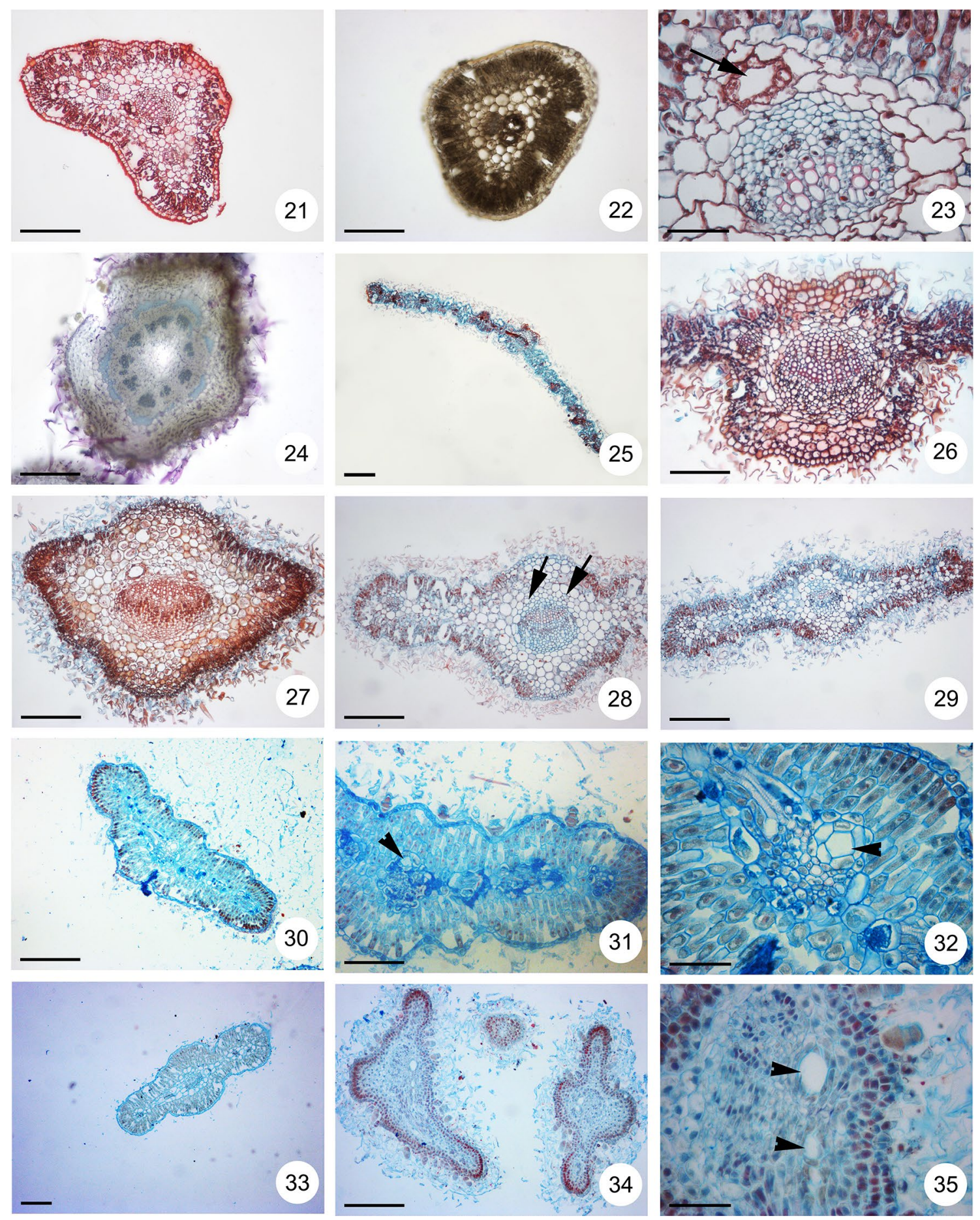

Figs. 21-35 Cross sections of the leaves of A. campestris (21, 22, 23), A. absinthium (24, 25, 26), A. arborescens (27, 28, 29), A. judaica (30, $31,32)$ and $A$. herba-alba $(33,34,35) .21,22,25,28,29,30,33$ General leaf anatomy showing amphistomatous leaves with isolateral structure and large stomatal chamber. 24, 27 Petiole anatomy. 23, 28, 31, 32, 35 Detail of the leaf anatomy showing secretory canals in the leaf parenchyma (23) (arrow), leaf base parenchyma (28) (arrows) and beyond the phloem of the vascular bundle $(31,32,35)($ arrowheads). Bar $=50 \mu \mathrm{m}$ in 23,32 and $35 ; 100 \mu \mathrm{m}$ in $31 ; 200 \mu \mathrm{m}$ in $21,22,24,25,26,27,28,29,30,33,34$

In the central leaf blade plane one large collateral closed vascular bundle could be noticed (Figs. 21, 26, 29, 30, 33 ). On the leaf cross sections of A. absinthium (Figs. 25,
26), A. arborescens (Figs. 28, 29), A. judaica (Figs. 30, 31 ) and $A$. herba-alba (Figs. 33, 34), the main vein is prominent with two lateral ribs, which are with many 
valleculae. Vascular bundle in the main vein of A. campestris (Figs. 21, 22), A. absinthium (Figs. 25, 26) and $A$. arborescens (Figs. 28, 29) is surrounded with parenchyma sheath, which in A. absinthium (Fig. 26) and A. arborescens (Figs. 28, 29) extend to both epidermises. In the main vein of A. absinthium (Fig. 26) and A. arborescens (Fig. 28) a subepidermal collenchyma could be seen on both leaf sides. Secretory canals are noticed in the leaf parenchyma of A. campestris (Figs. 21, 22, 23) and beyond the phloem of the vascular bundle of $A$. judaica (Figs. 30, 31, 32) and A. herba-alba (Figs. 33, 34, 35). In $A$. arborescens secretory canals are present in the leaf petiole parenchyma (Fig. 27) and in the leaf base parenchyma (Fig. 28).

Trichomes - On the aerial parts of all investigated species numerous nonglandular (Figs. 36, 37) as well as glandular (Figs. 38, 39) trichomes could be seen. Only exception could be noticed for A. campestris which possesses very few trichomes (Figs. 11, 21). Stems and leaves of all other species are densely covered with trichomes (Figs. 13, 15, 17, 19, $26,29,31,34)$. The nonglandular trichomes are T-shaped, with various variable number of cells which form a neck of the trichome, and with long curly or straight arms (Figs. 36, 37). Glandular trichomes are of biseriate type covered with cuticle sheath (Figs. 38, 39).

Major distinguishing qualitative anatomical characters and their states of all studied species are shown in Table 2.

\section{Discussion}

In the roots of all investigated species secretory canals were found, except of roots of A. herba-alba. Endodermal secretory canals were noticed in the roots of A. campestris, $A$. absinthium, A. arborescens and A. judaica, while nonendodermal secretory canals were found only in the secondary phloem of A. campestris and in the cortex of A. absinthium and $A$. judaica. Morphology and distribution of secretory structures have been used as diagnostic characters in recognition of the species within Asteraceae (Solereder 1908; Metcalfe and Chalk 1979, Castro et al. 1997; da Silva et al. 2014). Ivănescu et al. (2015) also found secretory canals in the cortex and phloem of the roots of A. absinthium, but we did not found canals in the phloem of this species. General root anatomy of $A$. absinthium was in accordance with those described by Ivănescu et al. (2015).

Internal secretory spaces of lipid substances occurring both in aerial and in underground organs are widely distributed among the species of the Asteraceae family (Fahn 1979). The various types of secretory canals found in the Asteraceae could be classified into two groups: (1) endodermal canals with an extra-endodermal position, but their formation is closely related to the endodermis and (2) nonendodermal canals, which are not connected with the endodermis and have schizo-lysigenous formation in the older stages of the root (Tetley 1925). Fatty substances are released during the phloem differentiation, and from phloem, it passes outward and deposited in the endodermal canals (Tetley 1925). Nonendodermal canals differed from the endodermal canals
Figs. 36-39 Nonglandular T-shaped $(36,37)$ and biseriate glandular trichomes, lateral view (38) and frontal view (39) of $A$. judaica (36), A. herbaalba $(37,38)$ and $A$. absinthium (39). $B a r=50 \mu \mathrm{m}$
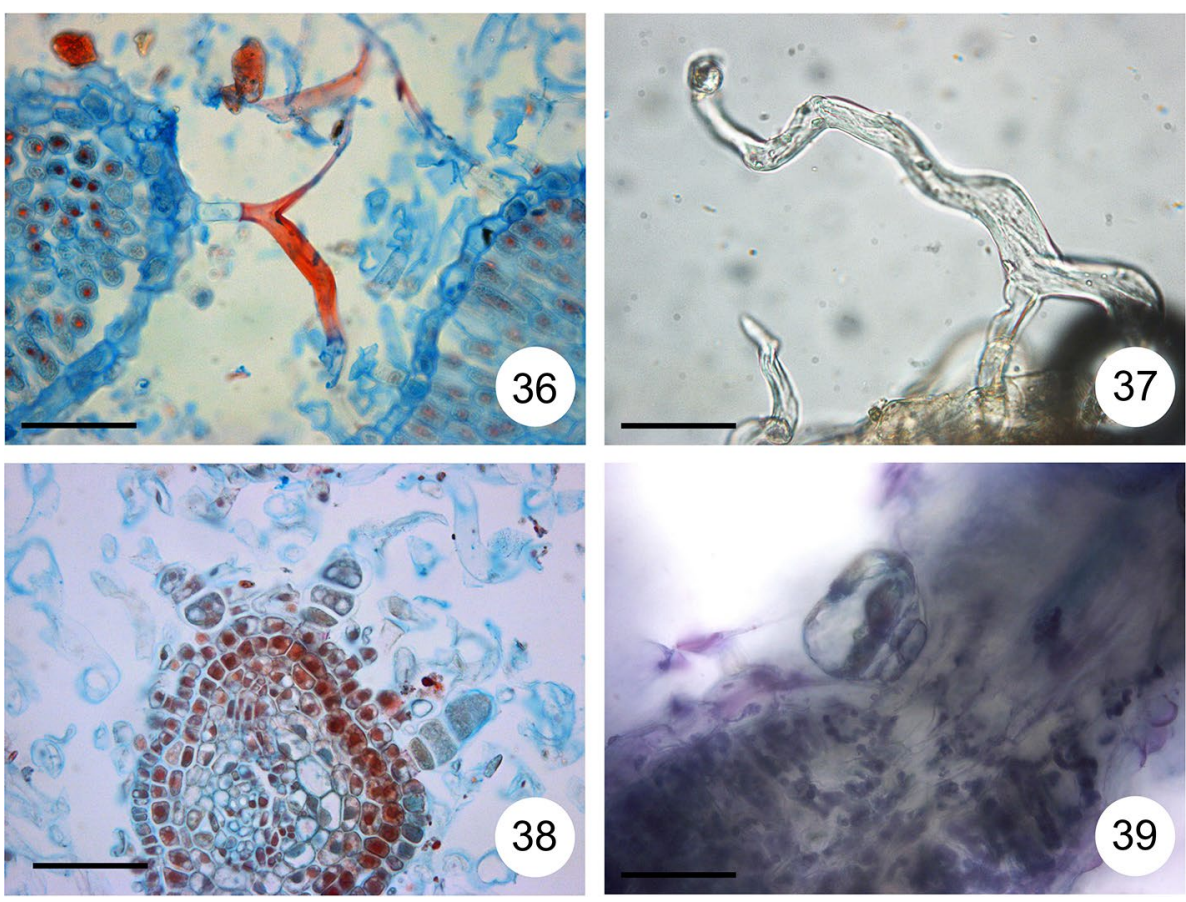
Table 2 Qualitative anatomical characters distinguishing examined Artemisia species

\begin{tabular}{|c|c|c|c|c|c|c|c|c|}
\hline Organ & Character & & & A. campestris & A. absinthium & $\begin{array}{l}\text { A. } \\
\text { arbore- } \\
\text { scens }\end{array}$ & A. judaica & A. herba-alba \\
\hline \multirow[t]{3}{*}{ Root } & \multirow[t]{3}{*}{ Secretory canals } & Endodermal & & + & + & + & + & - \\
\hline & & Nonendodermal & Cortex & - & + & - & + & - \\
\hline & & & Secondary phloem & + & - & - & - & - \\
\hline \multirow[t]{5}{*}{ Stem } & Periderm & & & + & - & + & - & - \\
\hline & $\begin{array}{l}\text { Lignified pith parenchyma } \\
\text { cells }\end{array}$ & & & + & - & + & - & - \\
\hline & $\begin{array}{l}\text { Crystals in pith parenchyma } \\
\text { cells }\end{array}$ & & & - & - & + & - & - \\
\hline & Secretory canals & & Cortex & + & + & + & + & + \\
\hline & & & Pith & - & + & - & - & - \\
\hline \multirow[t]{6}{*}{ Leaf } & Shape on cross section & & Triangular & + & - & - & - & - \\
\hline & & & Oblong-linear & - & + & + & + & + \\
\hline & Secretory canals & & Parenchyma & + & - & - & - & - \\
\hline & & & Phloem & - & - & - & + & + \\
\hline & $\begin{array}{l}\text { Parenchyma sheath, surround } \\
\text { vascular bundle, extend to } \\
\text { both epidermises }\end{array}$ & & & - & + & + & - & - \\
\hline & Subepidermal collenchyma & & & - & + & + & - & - \\
\hline
\end{tabular}

$-=$ represents the absence of character

in size, and they are shorter and possess epithelial-like cells which surround these canals (Tetley 1925). Cury and Appezzato-da-Glória (2009) have been shown that secretory structures have a significant role in plant defense against herbivores and pathogens. Also, they found cortical canals and cavities in roots, cavities in the roots secondary phloem, cortical cavities in the xylopodium and in the underground stem and canals in the secondary xylem in the xylopodium while investigating the secretory structures of six Asteraceae species belonging to the different tribes: Eupatorieae, Mutisiae and Vernonieae. In addition, it was shown that these structures possess lipid substances.

In the stem cortex of all investigated species secretory canals were also recorded, while only in the pith of A. absinthium small secretory canals were found additionally. Konowalik and Kreitschitz (2012) also found secretory canals in the stem cortex and pith of two varieties of $A$. absinthium. This character could be considered as specific for A. absinthium. Accumulations of resin-like compounds are remarkably abundant in Anthemideae and Ambrosieae (Carlquist 1966). Massive accumulations in at least a few vessels and massive accumulations or droplets in vessels and in other cell types in wood were recorded in A. absinthium and $A$. arborescens (Carlquist 1966). In addition, secretory canals are noticed in the leaf parenchyma of A. campestris and beyond the phloem of the vascular bundle of $A$. judaica and A. herba-alba. Secretory canals are found in the stem cortex and leaf mesophyll (Hoffmann et al. 1984;
Ponce 1986), often as a part of the bundle sheath. Most often one canal exists for a bundle, rarely two. Ascensão and Pais (1988) conducted investigation on ultrastructure and histochemistry of secretory canals in A. campestris subsp. maritima (DC.) Arcang. and found that the resin canals are distributed in the cortical parenchyma, in the proximity of the vascular bundles, and run longitudinally through the petiole and stem. In addition, the canal lumen, which is surrounded by two concentric layers of flattened cells, the epithelial and subepithelial, contains oleoresin. Moreover, plastids inside of canal epithelial cells may be involved in the terpenoids and polyacetylenes synthesis, while smooth endoplasmic reticulum and mitochondria in the steroids synthesis (Ascensão and Pais 1988). Also, the ultrastructure investigations of the secretory canals of Grindelia pulchella Dunal were also shown that plastids, mitochondria and endoplasmic reticulum are involved in the secretion (Bartoli et al. 2011). According to Bartoli et al. (2011), special tissue with "transfer cells" secretes the products and transferred to the canal epithelial cells where it accumulates in the vacuoles.

Besides secretory canals inside the organs, glandular trichomes at the organ surfaces are another secreting system present in Asteraceae plants (Bartoli et al. 2011). Indumentum features (shape, occurrence, distribution and density of glandular and nonglandular trichomes and stomata characteristics) represent valuable characters in taxonomy (Hayat et al. 2009). We documented numerous nonglandular T-shaped, as well as biseriate glandular trichomes on the 
aerial parts of all investigated species, except for A. campestris which was almost glabrous. Such a dense cover of trichomes is a known characteristic in xeromorphic plants, which help them to adapt to dry conditions by limiting transpiration, reflecting radiation or even might helping to absorb water (Ehleringer et al. 1976; Lyshede 1979). Pubescence may also be included in the control of water loss and temperature regulation (Johnson 1975; Ehleringer et al. 1976). Various types of glandular and nonglandular trichomes occur in Artemisia species and include multiseriate glandular trichomes, as well as nonglandular filamentous T-trichomes (Ferreira and Janick 1995). These types of trichomes were also found in A. absinthium from Romania (Ivănescu et al. 2015) and from Poland (Konowalik and Kreitschitz 2012), in A. campestris subsp. maritima (Ascensão and Pais 1987), in A. alba subsp. saxatilis (Willd.) P. Fourn. (Bercu and Broască 2012), in A. judaica var. sinaitica Tackholm (Bakr 2014), in A. judaica (Fahmy 1997) and in several Artemisia species (including A. absinthium) examined by Lodari et al. (1989). Hayat et al. (2010) stated that foliar epidermal anatomical characteristics are valuable taxonomic traits, which could help in resolving complex taxonomy within the genus Artemisia. Also, glandular trichomes were found as helpful taxonomic character for A. nova A. Nelson (Kelsey 1984). However, both nonglandular and glandular trichomes of the examined species were uniform. Glandular trichomes are usually consisted of a biseriate peduncle and a head which is formed of one to many cells. The peduncle is usually formed by five pairs of cells (Ciccarelli et al. 2007). Duke and Paul (1993) and Duke et al. (1994) described in detailed development of glandular trichomes in A. аппиа, the same as Ascensão and Pais (1987) for A. campestris subsp. maritima. Regarding glandular trichomes of G. pulchella, Bartoli et al. (2011) showed that the secretion is accumulated between the cell wall and the cuticle, which released the secretion when it breaks. It is documented that the secretion, of both, canals and trichomes, is composed of essential oils, lipids, sesquiterpene lactones, resins, pectinlike substances, alkaloids, flavonoids and tannins (Ascensão and Pais 1987, 1988; Pagni et al. 2003; Andreucci et al. 2008; Lusa et al. 2016; Gavrilović et al. 2018a).

Stem anatomy of the examined species could be considered as typical for the Asteraceae (Metcalfe and Chalk 1957 ) and is in accordance with previously described in the papers of Konowalik and Kreitschitz (2012) and Ivănescu et al. (2015) who studied anatomy of A. absinthium. Exception from typical anatomy could be seen in the presence of well-developed periderm found only in the stem of $A$. campestris and A. arborescens. Also, lignified walls of pith parenchyma cells were recorded only in these two species. Konowalik and Kreitschitz (2012) found that A. absinthium var. calcigena Rehm. was characterized with a continuous layer of periderm, formed in the early stage of development, and lignification of pith cells, which could be an effect of the dry calcareous habitat. Furthermore, Zhang et al. (2018) examined anatomy of A. lavandulaefolia DC. and A. selengensis Besser and demonstrated that barrier layers, like endodermis and exodermis, dilated endodermis and exodermis, air spaces and hypodermal periderm, provide roots, rhizomes and aerial stems with tissues which could enable the plants to withstand flooding. Why, in spite of living in dry habitats, A. absinthium, A. judaica and A. herba-alba do not form such a layer in the stem? We consider that many other Artemisia species should be anatomically investigated in order to define whether the presence of periderm in the stem represents a taxonomic character or it only reflects environmental conditions. In addition, Carlquist (1966), in his investigations on wood anatomy of the Anthemideae and three related tribes of Asteraceae, concluded that A. arborescens lack of adaptation to extreme ecological conditions in view of wood anatomy.

Rhomboidal crystals were found only inside the pith parenchyma cells of $A$. arborescens. The most often found minerals inside the plant cells are calcium oxalate (Korth et al. 2006), which were documented in many plant families (more than 215) (Molano-Flores 2001; Kartal 2016). These crystals occur in various plant tissues and organs (Horner et al. 2000, 2012; Ilarslan et al. 2001; Meric 2009a, b). The presence of crystals is in relation to many functions: calcium regulation within the cells (Kostman and Franceschi 2000; Volk et al. 2002), against herbivory (Molano-Flores 2001), detoxification of oxalic acid or heavy metals (Franceschi and Nakata 2005), strengthening the mechanical tissue and reflection and gathering of light (Franceschi and Horner 1980; Kuo-Huang et al. 2007). Within the cells, calcium oxalate crystals are described as raphides, druses, styloids, prisms or crystal sand (Franceschi and Horner 1980; Kartal 2016). These crystals were documented in previous studies in Asteraceae plants (Dormer 1961, 1962; Horner 1977; Meric and Dane 2004; Meric 2009a, b; Kartal 2016). The shapes and occurrence of crystals might be used as valid taxonomic characters (Prychid and Rudall 1999; Lersten and Horner 2000; Pennisi and McConnell 2001; Franceschi and Nakata 2005; Horner et al. 2012; Kartal 2016; Gavrilović et al. 2017), as it was considered that the formation of crystals inside the cells is under genetic control and speciesspecific (Horner et al. 2009; Ilarslan et al. 2001). Thus, these crystals could be specific to the $A$. arborescens.

Leaf on the cross section is triangular in A. campestris, while in other studied species is oblong-linear. Very welldeveloped cuticle was present in A. campestris, probably because this species barely possesses trichomes on its surface. Also, parenchyma sheath which surrounded main vascular bundle extended to both epidermises only in A. absinthium and $A$. arborescens. In addition, in the main vein a subepidermal collenchyma could be seen on both leaf sides 
of these two species. These characters could be of importance for taxonomy. Anatomically, leaf blade is in accordance with previously described leaf blade of $A$. judaica (Fahmy 1997), A. alba subsp. saxatilis (Bercu and Broască 2012) and A. judaica var. sinaitica (Bakr 2014) regarding isolateral leaf structure and amphistomatous leaves with large stomatal chamber, but in contrast to leaf anatomy of two varieties of $A$. absinthium, where stomata were found only on the abaxial side and where bifacial leaf structure was described (Konowalik and Kreitschitz 2012). Although leaf mesophyll, in Asteraceae plants, typically contains palisade and spongy tissue (Duarte et al. 2011; Jane et al. 2011; Gavrilović et al. 2018b), it is known that leaf anatomy often reflects environmental factors too. Plants with isolateral leaf structure usually grow on dry habitats with intense solar radiation, shown for the genera Aster L., Galatella Cass., Tripolium Nees. (Karanović et al. 2015), most of Centaurea species (Fahn and Cutler 1992; Luković et al. 2013), as well as recorded for our studied species. Also, the amphistomatic leaves are characteristic of plants growing in highly lighted habitats (Fahmy 1997). It is shown that over $90 \%$ of the species, in North American deserts, have amphistomatic leaves (Mott et al. 1982). Although leaf anatomical features are usually in relation with the environmental conditions, they are genetically controlled and thus are of taxonomic importance (Anderson and Creech 1975). Noorbakhsh et al. (2008) analyzed leaf anatomy of 28 Artemisia species (including A. absinthium) and recognized three groups which differ in their midrib shape, its position in relation to lamina and length and number of veins in each lamina half which is correlated with leaf morphology. According to Noorbakhsh et al. (2008) A. absinthium belongs to the first group due to the presence of a lot of collenchymatous tissues under epidermis, the midrib is voluminous and each half of lamina is long which is in accordance with our results.

Our results have shown that general root, stem and leaf anatomical features and nonglandular and glandular trichomes are shared by all species. However, some characters (parenchyma sheath, which surrounded vascular bundle and extended to both epidermises, subepidermal collenchyma and the absence of secretory canals in the leaves) link together A. absinthium and A. arborescens from the same section. Some characters, as periderm and lignified pith parenchyma cells (A. campestris and A. arborescens), nonendodermal secretory canals in root cortex $(A$. absinthium and A. judaica) and secretory canals in the leaf phloem ( $A$. judaica and $A$. herba-alba), connect species belong to different sections. Moreover, some characters could be considered as species-specific: nonendodermal secretory canals in the root secondary phloem, triangular leaf shape on the cross section and secretory canals in the leaf parenchyma for A. campestris; secretory canals in the stem pith for $A$. absinthium; crystals in the pith parenchyma cells for $A$. arborescens; and the absence of root secretory canals for $A$. herba-alba. The given results revealed qualitative characters on the basis of which the studied species are anatomically distinguishable between each other, provide valuable features for better species identification and contribute to the anatomy of the genus Artemisia.

Some of the anatomical characters obtained could be guideline for future investigations and thus useful in the delimitation of other Artemisia taxa. We consider that a comprehensive anatomical analysis, combined with micromorphological, phytochemical and molecular data, of the remaining Artemisia taxa, will certainly help in resolving their taxonomic and phylogenetic relationships.

Acknowledgements The authors thank to the Ministry of Education, Science and Technological Development of the Republic of Serbia for financial support (Grant No. 173029). Also, many thanks to Radenko Radošević, technical associate, from Faculty of Agriculture, University of Belgrade, for technical assistance in anatomical laboratory.

Author contributions PJ, MG and AAG conducted the field work. PJ, MG and DR conducted anatomical analysis. PJ, MG and DR wrote the manuscript. PJ, ZDS and PDM supervised the research and gave comments to the manuscript. All authors read and approved the final version of the manuscript.

\section{Compliance with ethical standards}

Conflict of interest The authors declare that they have no conflict of interest.

\section{References}

Anderson LC, Creech JB (1975) Comparative leaf anatomy of Solidago and related Asteraceae. Am J Bot 62:486-493

Andreucci AC, Ciccarelli D, Desideri I, Pagni AM (2008) Glandular hairs and secretory ducts of Matricaria chamomilla (Asteraceae): morphology and histochemistry. Ann Bot Fenn 45:11-18

Ascensão L, Pais MSS (1987) Glandular trichomes of Artemisia campestris (ssp. maritima): ontogeny and histochemistry of the secretory product. Bot Gaz 148:221-227

Ascensão L, Pais MS (1988) Ultrastructure and histochemistry of secretory ducts in Artemisia campestris ssp. maritima (Compositae). Nord J Bot 8:283-292

Ascensão L, Da Silva JAT, Barroso JG, Figueiredo AC, Pedro LG (2001) Glandular trichomes and essential oils of Helichrysum stoechas. Isr J Plant Sci 49:115-122

Bakr RO (2014) Microscopical and phytochemical investigation of Egyptian Artemisia judaica L. var. sinaitica Tackholm and its free radical scavenging activity. Int J Pharmacogn Phytochem Res 6:698-703

Bartoli A, Galati BG, Tortosa RD (2011) Anatomical studies of the secretory structures: glandular trichomes and ducts, in Grindelia pulchella Dunal (Astereae, Asteraceae). Flora 206:1063-1068

Bercu R, Broască L (2012) Histoanatomical features of Artemisia alba subsp. saxatilis (Willd.) P. Fourn. Ann Rom Soc Cell Biol 17:278-283

Botha CEJ, Evert RF (1981) Studies on Artemisia afra Jacq.: the phloem in stem and leaf. Protoplasma 109:217-231 
Camilotti JG, Biu CC, Farago PV, Pereira dos Santos VL, Franco CRC, Budel JM (2014) Anatomical characters of leave and stem of Calea serrata Less., Asteraceae. Braz Arch Biol Techn 57:867-873

Carlquist S (1958) Structure and ontogeny of glandular trichomes of Madinae (Compositae). Am J Bot 45:675-682

Carlquist S (1966) Wood anatomy of Anthemideae, Ambrosieae, Calenduleae and Articotideae (Compositae). Aliso 6:1-23

Castro MDM, Leitão-Filho HDF, Monteiro WR (1997) Utilização de estruturas secretoras na identificação dos gêneros de Asteraceae de uma vegetação de cerrado. Braz J Bot 20:163-174

Ciccarelli D, Garbari F, Pagni AM (2007) Glandular hairs of the ovary: a helpful character for Asteroideae (Asteraceae) taxonomy? Ann Bot Fenn 44:1-7

Cury G, Appezzato-da-Glória B (2009) Internal secretory spaces in thickened underground systems of Asteraceae species. Aust J Bot 57:229-239

da Silva EMS, Hayashi AH, Appezzato-da-Glória B (2014) Anatomy of vegetative organs in Aldama tenuifolia and A. kunthiana (Asteraceae: Heliantheae). Braz J Bot 37:505-517

Dengler NG (2002) An integral part of botany: book review. Am J Bot 89:369-374

Dormer KJ (1961) The crystals in the ovaries of certain Compositae. Ann Bot-Lond 25:241-254

Dormer KJ (1962) The taxonomic significance of crystal forms in Centaurea. New Phytol 61:32-35

Duarte MR, Budel JM, Matzenbacher NI, Menarim DO (2011) Microscopic diagnosis of the leaf and stem of Lucilia nitens Less., Asteraceae. Lat Am J Pharm 30:2070-2075

Duke SO, Paul RN (1993) Development and fine structure of glandular trichomes of Artemisia annua L. Int J Plant Sci 154:107-118

Duke MV, Paul RN, Elsohly HN, Sturtz G, Duke SO (1994) Localization of artemisinin and artemisitene in foliar tissues of glanded and glandless biotypes of Artemisia annua L. Int J Plant Sci 155:365-372

Ehleringer JR, Bjorkman O, Mooney HA (1976) Leaf pubescence: effects on absorbance and photosynthesis in a desert shrub. Science 192:376-377

Fahmy GM (1997) Leaf anatomy and its relation to the ecophysiology of some non-succulent desert plants from Egypt. J Arid Environ $36: 499-525$

Fahn A (1979) Secretory tissues in plants. Academic Press Inc., London

Fahn A, Cutler FD (1992) Xerophytes. Encyclopedia of plant anatomy, vol XIII, Part 3. Gebrüder Borntraeger, Berlin

Ferreira JF, Janick J (1995) Floral morphology of Artemisia annua with special reference to trichomes. Int J Plant Sci 156:807-815

Figueiredo AC, Pais MSS (1994) Ultrastructural aspects of the glandular cells from the secretory trichomes and from the cell suspension cultures of Achillea millefolium L. ssp. millefolium. Ann Bot-Lond 74:179-190

Franceschi VR, Horner HT Jr (1980) Calcium oxalate crystals in plants. Bot Rev 46:361-427

Franceschi VR, Nakata PA (2005) Calcium oxalate in plants: formation and function. Annu Rev Plant Biol 56:41-71

Garcia S, Sanz M, Garnatje T, Kreitschitz A, McArthur ED, Vallès J (2004) Variation of DNA amount in 47 populations of the subtribe Artemisiinae and related taxa (Asteraceae, Anthemideae): karyological, ecological, and systematic implications. Genome 47:1004-1014

Gavrilović M, Soković MD, Stanković M, Marin PD, Stevanović ZD, Janaćković P (2016) Antimicrobial and antioxidative activity of various leaf extracts of Amphoricarpos Vis. (Asteraceae) taxa. Arch Biol Sci 68:803-810

Gavrilović M, Erić S, Marin PD, Garcia-Jacas N, Susanna A, Janaćković P (2017) Scanning electron microscopy coupled with energy dispersive spectrometric analysis reveals for the first time weddellite and sylvite crystals on the surface of involucral bracts and petals of two Xeranthemum L. (Compositae) species. Microsc Microanal 23:679-686

Gavrilović M, Tešević V, Đorđević I, Rajčević N, Bakhia A, Garcia-Jacas N, Susanna A, Marin PD, Janaćković P (2018a) Leaf micromorphology, antioxidative activity and a new record of 3-deoxyamphoricarpolide of relict and limestone endemic Amphoricarpos elegans Albov (Compositae) from Georgia. Arch Biol Sci 70:613-620

Gavrilović M, Rančić D, Škundrić T, Dajić-Stevanović Z, Marin PD, Garcia-Jacas N, Susanna A, Janaćković P (2018b) Anatomical characteristics of Xeranthemum L. (Compositae) species: taxonomical insights and evolution of life form. Pak J Bot. https:// doi.org/10.30848/pjb2019-3(26)

Hayat MQ, Ashraf M, Khan MA, Yasmin G, Shaheen N, Jabeen S (2009) Diversity of foliar trichomes and their systematic implications in the genus Artemisia (Asteraceae). Int J Agric Biol 11:542-546

Hayat MQ, Ashraf M, Jabeen S, Shaheen N, Yasmin G, Khan M (2010) Taxonomic implications of foliar epidermal characteristics with special reference to stomatal variations in the genus Artemisia (Asteraceae). Int J Agri Biol 12:221-226

Hoffmann J, Kingsolver B, McLaughlin S, Timmermann B (1984) Production of resins by arid-adapted Asteraceae. In: Timmermann BN, Steelink C, Loewus F (eds) Phytochemical adaptations to stress. Plenum Press, New York, pp 251-271

Horner HT (1977) A comparative light and electron-microscopic study of microsporogenesis in male-fertile and cytoplasmic male-sterile sunflower (Helianthus annuus). Am J Bot 64:745-759

Horner HT, Kausch AP, Wagner BL (2000) Ascorbic acid: a precursor of oxalate in crystal idioblasts of Yucca torreyi in liquid root culture. Int J Plant Sci 161:861-868

Horner HT, Wanke S, Samain MS (2009) Evolution and systematic value of leaf crystal macropatterns: a phylogenetic approach in the genus Peperomia (Piperaceae). Int J Plant Sci 170:343-354

Horner HT, Wanke S, Samain MS (2012) A comparison of leaf crystal macropatterns in the two sister genera Piper and Peperomia (Piperaceae). Am J Bot 99:983-997

Ilarslan H, Palmer RG, Horner HT (2001) Calcium oxalate crystals in developing seeds of soybean. Ann Bot-Lond 88:243-257

Ivănescu B, Miron A, Lungu C (2015) Histo-anatomy of vegetative organs of some Artemisia species. Med-Surg J 119:917-924

Jane MB, Duarte MDR, Farago PV, Franco CR, Santos VL, Oliveira A (2011) Comparative morpho-anatomical study of Baccharis curitybensis Heering ex Malme and Baccharis spicata (Lam.) Baill. Lat Am J Pharm 30:1560-1566

Johansen DA (1940) Plant microtechnique. McGraw-Hill Book Company, New York

Johnson HB (1975) Plant pubescence: an ecological perspectives. Bot Rev 41:233-253

Karanović D, Luković J, Zorić L, Anačkov G, Boža P (2015) Taxonomic status of Aster, Galatella and Tripolium (Asteraceae) in view of anatomical and micro-morphological evidence. Nord J Bot 33:484-497

Kartal C (2016) Calcium oxalate crystals in some species of the tribe Cardueae (Asteraceae). Bot Sci 94:107-119

Kelsey RG (1984) Glandular trichomes: a helpful taxonomic character for Artemisia nova (black sagebrush). J Range Manag 37:370-372

Konowalik K, Kreitschitz A (2012) Morphological and anatomical characteristics of Artemisia absinthium var. absinthium and its Polish endemic variety A. absinthium var. calcigena. Plant Syst Evol 298:1325-1336

Korth KL, Doege SJ, Park SH, Goggin FL, Wang Q, Gomez SK, Liu G, Jia L, Nakata PA (2006) Medicago truncatula mutants 
demonstrate the role of plant calcium oxalate crystals as an effective defense against chewing insects. Plant Physiol 141:188-195

Kostman TA, Franceschi VR (2000) Cell and calcium oxalate crystals growth is coordinated to achieve high-capacity calcium regulation in plants. Protoplasma 214:166-179

Kreitschitz A, Vallès J (2007) Achene morphology and slime structure in some taxa of Artemisia L. and Neopallasia L. (Asteraceae). Flora 202:570-580

Kuo-Huang LL, Ku MSB, Franceschi VR (2007) Correlations between calcium oxalate crystals and photosynthetic activities in palisade cells of shade-adapted Peperomia glabella. Bot Stud 48:155-164

Lersten NR, Curtis JD (2001) Idioblasts and other unusual internal foliar secretary structures in Scrophulariaceae. Plant Syst Evol 227:63-73

Lersten NR, Horner HT (2000) Calcium oxalate crystals types and trends in their distribution patterns in leaves of Prunus (Rosaceae: Prunoideae). Plant Syst Evol 224:83-96

Lestern NR, Curtis JD (1985) Distribution and anatomy of hydathodes in Asteraceae. Bot Gaz 146:106-114

Lodari C, Hattori K, Futsuhara Y (1989) Morphological difference on leaf surface and pollen grains in genus Artemisia. Jpn J Breed 39:9-12

Luković J, Malenčić D, Zorić L, Kodranov M, Karanović D, Kiprovski B, Boža P (2013) Anatomical characteristics and antioxidant ability of Centaurea sadleriana reveals an adaptation towards drought tolerance. Cent Eur J Biol 8:788-798

Lusa MG, Da Costa FB, Appezzato-da-Glória B (2016) Histolocalization of chemotaxonomic markers in Brazilian Vernonieae (Asteraceae). Bot J Linn Soc 182:581-593

Lyshede OB (1979) Xeromorphic features of three stem assimilants in relation to their ecology. Bot J Linn Soc 78:85-98

Maghni B, Hellal B, Maatoug M (2018) Dynamics of the anatomical variability of Artemisia herba-alba in Algeria. Biosyst Divers 26:239-244

Marchese JA, Broetto F, Ming LC, Ducatti C, Rodella RA, Ventrella MC, Gomes GDR, Franceschi LD (2005) Carbon isotope composition and leaf anatomy as a tool to characterize the photosynthetic mechanism of Artemisia anпиa L. Braz J Plant Physiol 17:187-190

McArthur ED, Plummer AP (1978) Biogeography and management of native western shrubs: a case study, section Tridentatae of Artemisia. Great Basin Nat 2:229-243

Meric C (2009a) Calcium oxalate crystals in some species of the tribe Inuleae (Asteraceae). Acta Biol Crac Ser Bot 51:105-110

Meric C (2009b) Calcium oxalate crystals in Aster squamatus and Bellis perennis (Asteraceae: Astereae). Phytol Balc 15:255-259

Meric C, Dane F (2004) Calcium oxalate crystals in floral organs of Helianthus annuus L. and $H$. tuberosus L. (Asteraceae). Acta Biol Szeged 48:19-23

Metcalfe CR (1983) Secretory structures: cells, cavities and canals in leaves and stems. Laticifers and latex. In: Metcalfe CR, Chalk L (eds) Anatomy of the dicotyledons. Wood, structure and conclusion of the general introduction. Clarendon Press, Oxford, pp 64-97

Metcalfe CR, Chalk L (1950) Anatomy of the dicotyledons: leaves, stem, and wood in relation to taxonomy with notes on economic uses, vol 2. Clarendon Press, Oxford

Metcalfe CR, Chalk L (1957) Anatomy of the dicotyledons, vol 2. Clarendon Press, Oxford

Metcalfe CR, Chalk L (1979) Anatomy of dicotyledons: systematic anatomy of the leaf and stem, with a brief history of the subject, vol 1. Claredon Press, Oxford

Molano-Flores B (2001) Herbivory and calcium concentrations affect calcium oxalate crystal formation in leaves of Sida (Malvaceae). Ann Bot-Lond 88:387-391
Mott KA, Gibson AC, O'Leary JW (1982) The adaptive significance of amphistomatic leaves. Plant Cell Environ 5:455-460

Noorbakhsh SN, Ghahreman A, Attar F, Mahdigholi K (2008) Leaf anatomy of Artemisia (Asteraceae) in Iran and its taxonomic implications. Iran J Bot 14:54-69

O'Brien TP, Feder N, McCully ME (1964) Polychromatic staining of plant cell walls by toluidine blue O. Protoplasma 59:368-373

Pagni AM, Orlando R, Masini A, Ciccarelli D (2003) Secretory structures of Santolina ligustica Arrigoni (Asteraceae), an Italian endemic species. Isr J Plant Sci 51:185-192

Pareto G (1985) Artemisie. Ricerca ed applicazione. Quaderni Agricoli, supplemento 2:1-261

Pellicer J, Garnatje T, Molero J, Pustahija F, Siljak-Yakovlev S, Vallès J (2010) Origin and evolution of the South American endemic Artemisia species (Asteraceae): evidence from molecular phylogeny, ribosomal DNA and genome size data. Aust J Bot 58:605-616

Pennisi SV, McConnell DB (2001) Taxonomic relevance of calcium oxalate cuticular deposits in Dracaena Vand. ex L. HortScience 36:1033-1036

Ponce MM (1986) Morfología ecológica de plantas saxícolas del Cerro de la Ventana, Provincia de Buenos Aires, Argentina. Darwiniana 27:237-271

Prychid CJ, Rudall PJ (1999) Calcium oxalate crystals in monocotyledons: a review of their structure and systematics. Ann Bot-Lond 84:725-739

Rabie M, Jalili A, Zarrinkamar F (2006) Anatomical characteristics of five Artemisia species in the north of Iran. Pajouhesh \& Sazandegi 70:79-87

Ruzin SE (1999) Plant microtechnique and microscopy. Oxford University Press, Oxford

Sanz M, Vilatersana R, Hidalgo O, Garcia-Jacas N, Susanna A, Schneeweiss GM, Vallès J (2008) Molecular phylogeny and evolution of floral characters of Artemisia and allies (Anthemideae, Asteraceae): evidence from nrDNA ETS and ITS sequences. Taxon 57:66-78

Scatena VL, Giulietti AM, Borba EL, Van den Berg C (2005) Anatomy of Brazilian Eriocaulaceae: correlation with taxonomy and habitat using multivariate analyses. Plant Syst Evol 253:1-22

Simpson BB (2009) Economic importance of compositae. In: Funk VA, Susanna A, Stuessy TF, Bayer RJ (eds) Systematics, evolution and biogeography of compositae. IAPT, Vienna, pp 45-58

Solereder H (1908) Systematic anatomy of the dicotyledons: a handbook for laboratories of pure and applied botany, vol 1. Clarendon Press, Oxford

Sosa MM, Via do Pico GM, Dematteis M (2014) Comparative anatomy of leaves and stems in some species of the South American genus Chrysolaena (Vernonieae, Asteraceae) and taxonomic implications. Nord J Bot 32:611-619

Tan RX, Zheng WF, Tang HQ (1998) Biologically active substances from the genus Artemisia. Planta Med 64:295-302

Tetley U (1925) The secretory system of the roots of the Compositae. New Phytol 24:138-162

Torrell M, Garcia-Jacas N, Susanna A, Vallès J (1999) Infrageneric phylogeny of the genus Artemisia L. (Asteraceae, Anthemideae) based on nucleotide sequences of nuclear ribosomal DNA internal transcribed spacers (ITS). Taxon 48:721-736

Vallès J, Garnatje T (2005) Artemisia and its allies: genome organization and evolution and their biosystematic, taxonomic and phylogenetic implications in the Artemisiinae and related subtribes (Asteraceae, Anthemideae). In: Sharma A (ed) Plant genome: biodiversity and evolution, vol 1B. Phanerogams. Science Publishers, Enfield, pp 255-285

Vallès J, Torrell M, Garnatje T, Garcia-Jacas N, Vilatersana R, Susanna A (2003) The genus Artemisia and its allies, phylogeny of the subtribe Artemisiinae (Asteraceae, Anthemideae) based on nucleotide 
sequences of nuclear ribosomal DNA internal transcribed spacers (ITS). Plant Biol 5:274-284

Volk GM, Lynch-Holm VJ, Kostman TA, Goss LJ, Franceschi VR (2002) The role of druse and raphide calcium oxalate crystals in tissue calcium regulation in Pistia stratiotes leaves. Plant Biol 4:34-45

Watson LE, Bates PL, Evans TM, Unwin MM, Estes JR (2002) Molecular phylogeny of subtribe Artemisiinae (Asteraceae), including Artemisia and its allied and segregate genera. BMC Evol Biol 2:17

Werker E, Fahn A (1981) Secretory hairs of Inula viscosa (L.) Ait.development, ultrastructure, and secretion. Bot Gaz 142:461-476
Zhang X, Yang C, Seago JL (2018) Anatomical and histochemical traits of roots and stems of Artemisia lavandulaefolia and A. selengensis (Asteraceae) in the Jianghan Floodplain, China. Flora 239:87-97

Publisher's Note Springer Nature remains neutral with regard to jurisdictional claims in published maps and institutional affiliations. 